\title{
Articles
}

Central European Review of Economics \& Finance

Vol. 22, No. 6 (2017), pp. 41-55. D0l: 10.24136/ceref.2017.026

Bogusław Ślusarczyk ${ }^{1}$, Bożena Sowa ${ }^{2}$

\section{THE ECONOMIC CRISIS - ITS CAUSES AND RESULTS AND THE LIMITING VENTURES (SELECTED ASPECTS)}

Economic crisis, which took place in the years 2008-2009, was one of the biggest crises, which affected the world's economy. It began in the United States, and then it moved through most countries in the world, especially the highly developed, and the effects of this crisis have been very painful for the entire global economy. It should be stressed that the framework of the economic crisis include the period 2008-2010, although its roots go back to an earlier period than 2008, and its consequences - according to the authors - will be felt for many years. In the wide range, the financial crisis referred to the economic collapse, caused by making the wrong decisions by the monetary authorities of individual countries, unskilful actions of speculators and recession on the course of business cycle. Undoubtedly it was globalisation which contributed to such state, which has led to a great openness of economies, which in turn resulted in the transfer between all economic phenomena, both the positive and the negative. Moreover, globalisation caused the fact that crisis phenomena are growing strong, more and more noticeable and faster and faster move between individual countries. Trade and financial relations, and (perhaps most importantly) the panic in the markets, are responsible for this process.

\section{JEL Classification Codes: E43.}

Keywords: economic crisis, globalization, financial problems, banks, interest rates.

\footnotetext{
${ }^{1}$ Associate Professor, Ph.D., University of Rzeszów, Faculty of Economics, Department of Macroeconomics and International Relations.

${ }^{2}$ Assistant Professor, Ph.D., WSPiA University of Rzeszów in Rzeszów, College of Administration, Management and Business, Department of Management Science and Economics
} 


\section{Introduction}

A characteristic feature of each country's economy is its cyclicity and consecutive economic growths and declines, which are connected with the periodicity and which are its integral part. Modern world economy is an economy of very strict relationships among individual countries, and the economic fluctuations of one country affect other countries.

Globalization has led to very open economies, which results in the transfer between them of any economic phenomena, both positive and negative. Moreover, it caused the crisis phenomena to be stronger, more noticeable and to transfer faster between individual countries. Business and financial relations, as well as (or perhaps most importantly) the panic on the markets, are responsible for this process. History shows that it is not the lack of synchronization between the economic cycles is the biggest threat to the countries, but their imprudent policy, lack of appropriate financial supervision and speculations.

Modern economic crisis, which took place in the years 2008-2009, was one of the biggest crises which hit the world economy. The crisis began in the United States of America, and then it passed through most of world's countries, especially well-developed. The effects of the crisis were very severe for the whole world's economy (Adamczyk, 2012, p. 13) and it is considered to be the most extensive in the post-war period.

It should be mentioned that identifying modern crisis with recession - periodic reduction in the absolute level of production (Kołodko, 2010, p. 82) - is both intellectually and politically incorrect simplification.

The aim of the following article is the analysis of the influence of the economic crisis (The United States, Poland) on the consumers' behaviours on the banking products market in the context of the credit policy of commercial banks.

\section{Economic crisis in the United States and in Europe}

As a result of dynamic economic development in the years 2003-2006, especially of the emerging markets (emerging economies), the first indications of the overheating of the economy appeared in the United States (2007), which was manifested through: inadequate production capacity in relation to demand, limitation in the availability of qualified workforce, inflationary pressure, as well as growing trade deficit (Adamiec, Russel, 2009, p. 7). 
In case of normal economic cycle in such conditions the slowdown of economic development takes place, followed by the return to the dynamics adequate to the economic potential. However, a serious imbalance on the real estate market, which appeared in that period of time, destabilized the process. Among the main factors which led to the spread of global economic crisis, excessive risk appetite is mentioned, which was connected with the successive FED interest rate cut, as well as the desire to maximize profits by investors.

Low and falling interest rates in the United States since 2001, caused the increase of the number of mortgage loans granted by banks for the purchase of a residential real estate, and thus they led to dynamic growth in their prices. What is more, the growth of the demand for the above mentioned real estate was boosted by the relaxation of the assessment criteria on the part of the lenders, which means that the loans were granted to people of with poor or unsatisfactory credit history, which was associated with a high risk. In addition, taking mortgage loans was encouraged by the low initial interest rates, which increased dynamically upon the expiry of the preliminary period, making them attractive for borrowers establishing a new mortgage. Therefore, there was an intensive growth of the market of subprime loans, which initiated the phenomenon of securitization (Owsiak, 2003, p. 744) ( $^{3}$ of mortgage loans, which is a process based on the transfer of liability of credit risk from the lender to the investor.

The increase of the interest rates in the years 2006-2007 in the United States with the simultaneous fall of the prices of residential properties caused the inability of a significant group of the higher risk borrowers to repay their loans in case of increased interests. The higher risk borrowers had particular problems with the settlement of the raised loan liabilities as they were overwhelmed by the interests (Prosser, 2008).

The speculative bubble on the mortgage credit markets began to burst in the second half of 2007 when the bubbles started to inform about the incurred losses, as well as the threat of bankruptcy. By the end of 2007 tens of financial institutions announced their insolvency. Simultaneously worsening

\footnotetext{
${ }^{3}$ Securitization is a modern financial operation which enables businesses, financial institutions and banks to raise capital. The name of the operations is derived from the word securities. It is a conversion of liabilities into securities. It is used when within the framework of creditordebtor relations the operators decide to substitute the assets e.g. in the form of liabilities, into securities (shares) or debt (commercial papers, bonds), but those that are more easily transferable than e.g. the classic receivables.
} 
economic situation led FED to lower the interest rates drastically - to $2 \%$ in 2007 , as well as to grant to commercial banks loans amounting to the total sum of 41 billion of USD (Rymarczyk, 2010, p. 17-19).

The toughest moments for the financial markets took place in 2008 when Bear Stearns bank collapsed in March and Merrill Lynch, Goldman Sachs, Morgan Stanley, Lehman Brothers and Citigroup banks were considered potentially at risk of bankruptcy and thus they were recapitalized by the State. Despite this support, Lehman Brothers and Merrill Lynch declared insolvent, and the biggest insurance firm AIG as well as financial institutions of insurance market of the USA, Fannie Mae and Freddie Mac, were taken over by the State.

As a result of dynamic spread of the crisis, the American government decided to make further interventions. In October 2008, a so called Paulson's plan ${ }^{4}$ was adopted, the aim of which was to recapitalize financial sector for 700 billion USD. In the wake of bankruptcy of several important banks, as well as the growing risk of bankruptcy of another banks, there was a serious crisis of confidence in the interbank market.

Decreasing liquidity on the interbank market, but also declining level of consumption and production, growth of unemployment and the level of indebtedness caused the fact that FED decided (in December 2008) to reduce the level of interest rates to historically low level of $-0.25 \%$.

Another negative consequence of the limited supply of loans by banks was the fall of car sale. In 2009 the American government, in order to protect motor magnates Chrysler and General Motors from bankruptcy, decided to recapitalize these corporation for the amount of over a dozen billion USD.

Both in the banking and motor sector there were drastic job cuts. Only in 2008, 2.6 million people lost their jobs and it has been the worst result since the Second World War and the unemployment rate was $7 \%$ at that time. At the end of September 2008, the perturbations of the economy plunged in crisis caused sharp decline in American stock index, Dow Jones Industrial Average, which dropped during one session by about $7 \%$. Standards \& Poor's and NASDAQ indexes declined by about $9 \%$ and it was the biggest singlesession drop in 21 years. Due to the decline in GDP growth in most countries

\footnotetext{
${ }^{4}$ Paulson's Plan - Emergency Economic Stabilization Act of 2008 (EESA) - rescue package for the US financial sector, proposed during the financial crisis in the US in 2008 by Henry Paulson, Treasury Secretary in the office of George W. Bush. The main objective of this plan was the buyout of bad debts from the market which were granted by banks to customers who were not able to repay them.
} 
of the world in 2008 and unfavorable forecasts for the future there was a decline in commodity prices, especially crude oil and copper. The prices of oil dropped from over 140 USD per barrel to less than 40 USD, whereas the price of copper dropped from over 9 thousands to nearly 3 thousand USD per ton (Rymarczyk, 2010, p. 17-19).

According to the estimates of International Monetary Fund by October 2008 the losses caused by the crises in the USA amounted to 1.4 billion USD (which is approx. 10\% GDP), of which 750 billion were mortgage loans, and 650 billion USD were other "toxic papers”. However, the losses were probably smaller, as these estimates referred to the then market value of loans, rather than to actual losses.

One of the reasons for the deepening of the crisis in the USA in September and October of 2008 was the deterioration of the foreign investors' trust to the American market, and their decision to make investments in other regions of the world. However, as it soon turned out other world markets, although a bit later, also had turbulence, the consequence of which was the return of foreign capital to the USA at the end of 2008 and slight relaxation of still deteriorating economic situation (Małkiewicz, 2010, p. 98).

After a moderate pickup in the first half of the year (by $0.9 \%$ in the first quarter and by $2.8 \%$ in the second quarter) national income (GDP) of the Unites States decreased in the third quarter of 2008 by $0.5 \%$, and in the fourth quarter by $6.3 \%$, which was the biggest quarterly decline in GDP recorded in the US economy since 1982. As a consequence the national income of the US increased in 2008 only by $1.1 \%$, which was much less than in $2007-2.0 \%$ and in $2006-2.8 \%$ (Firlej 2011, no. 4, p. 184-185).

In 2009 in connection to the unsatisfactory effects of corrective actions initiated in the previous year by the administration of President Bush, the new administration of President Obama, along with the Fed, decided to take further initiatives aimed at stimulating the US economy. In February 2009 the American Recovery and Reinvestment Act, so called ARRA, was adopted for the amount of 787 billion USD.

The program included the implementation of tax credits and benefits and to finance by the State the investment programs, inter alia: in terms of health, education and modernization of energy infrastructure. The US government also took endeavours which aimed to support homeowners having problems with the repayment of their loans. Help was based on the alleviation of the conditions of repayment of loans, as well as the reduction of the auctions of houses seized by banks for unpaid loans. 
The amount of monthly rate was limited to the level of $31 \%$ of the owner's income and the repayment of the remaining part of the loan was rescheduled. In 2009 there was the decrease in consumption by the Americans which was connected with the employment reduction, as well as their serious personal debts. Due to the difficult financial situation, households tended more towards savings than spending. In 2009 only part of ambitious goals of ARRA were managed to implement. One of them was the stimulation of economy, which increased in the third quarter. In the first quarter of 2009 the fall in GDP in the US was still big (-5.5\%), however in the second quarter it decreased significantly to $-0.7 \%$. In the third quarter of 2009 there was a growth by $2.2 \%$, and in the fourth quarter - in comparison to the third quarter - by $5.79 \%$. On the other hand, the situation on the labour market worsened. The unemployment was gradually increasing in the following months of the year so that in the last quarter of 2009 it amounted to 10\% (Firlej 2011, no. 4, pp. 184-185).

In the initial stages of the financial crisis in the United States, the economic situation of countries of Western Europe seemed to be relatively favourable, but over time it was changing. With the development of the crisis in the United States, some countries in Western Europe increasingly felt its significant impact.

European banks, in comparison to their American counterparts, led in the past a bit more responsible policy, thanks to which they survived the hardest phase of the crisis with relatively small losses, though not without a few bankruptcies. The biggest bankrupts one can include: Belgian-Dutch Fortis, British Royal Bank of Scotland, Irish Anglo-Irish Bank. Iceland had very big problems, as the entire banking system collapsed there. In Great Britain the Northern Rock bank, which - as it turned out - invested too much in American mortgage bonds, was nationalized. British government also decided to lend to banks in a difficult financial situation and took a share of some of them. In Germany a rescue package for Hypo Real Estate bank was established. The governments of many Western European countries decided to support the financial sector. Rescue packages prepared by Britain, Germany, France, Austria, Italy and Portugal provided for assistance in the amount of EUR 1.85 trillion in the form of guarantees, loans and recapitalization for banks (Rymarczyk, 2010, p. 18).

The most serious effects of the crisis reflected themselves in the real economy. GDP of UE in 2008 amounted only $0.3 \%$ and a year later it fell to the level of $-4.3 \%$. Particularly acute decline in GDP was recorded in Ireland, whose economy shrank in 2008 and 2009 respectively by $-3.5 \%$ and $-7.6 \%$. 
The decline in GDP of Germany, which is the engine of the EU economy, was alarming. German economy shrank in 2009 by $-4.7 \%$. Among the EFTA countries most acute decline in domestic production was recorded in Iceland, where it was $-6.8 \%$. Individual countries were affected by the crisis in a varying ways, and often the biggest problems reached the countries which were flourishing in the pre-crisis period of time. In relation to the crisis, which was quickly spreading to the whole economy, the industrial production, export and retail were dropping and the unemployment increased (Małkiewicz, 2010, p. 101-102).

Of all the countries of Western Europe the most drastic consequences of the financial crisis hit: Greece, Spain, Ireland and Iceland. The crisis of reek economy of the recent years is connected with excessive public finances deficit. At the time of accession of Greece to the euro zone it was noted, that this country does not fulfil the convergence criteria, however strenuous efforts of the political authorities and the concealment of the true state of the Greek state finances meant that ultimately Greece joined the euro zone (Sytuacja gospodarcza ..., p. 1 and next).

The reason for the current economic difficulties in Greece is a progressive decline in the country's competitiveness in the international arena, as well as the excessive wage growth in the pre-crisis period. In order to create a semblance that it is possible to bring the country's deficit below 3\% of GDP, Greece falsified statistics for the needs of the EU institutions. It is estimated that in 2010 the public debt of Greece amounted to 120 billion EUR. Whereas the foreign debt in March 2010 amounted to 391 billion EUR, and so $163 \%$ of GDP (Sytuacja gospodarcza ..., p. 1 and next).

It should be noted that the Greek economy has functioned in the recent years over its possibilities, financing needs mainly from foreign loans. Money from this source was mainly used to increase wages in the public sector. Some salaries have increased over the last five years by up to $100 \%$, and the additional destructive factor for the Greek economy was the fact that the government was tolerating tax evasion by citizens. The outbreak of the global financial crisis in 2008 totally surprised the Greek economy, which was unprepared to resist, which led to the cumulation of the country's problems.

Financial problems of Spanish economy, as opposed to Greece, were not connected with expenditure, but with revenue. More than $50 \%$ of the proceeds to the Spanish budget from taxes was associated with the real estate market, which in the recent years has been very similar to the real estate market in the United States. The total value of investments in real estate in 
2006-2007 in Spain amounted to one third of GDP, which means that the Spaniards then built more real estate than the French and Germans together.

Since the bubble burst, on the real estate market in 2007 there was a decline in property prices by approx. $15-20 \%$, which resulted in the cessation of new investment, dynamic increase of unemployment and drop in tax revenue to the budget. Ireland, on the other hand, was the country from euro zone which was absorbed by the financial crisis. The main reason for this state of affairs was mainly the external financing of the investments in a very powerful construction sector, which was the flywheel to the Irish economy; there was a rapid increase in property prices, and Ireland's GDP growth was based largely on the so-called real estate bubble.

As a result of the world's financial crisis, there were staff cuts in enterprises and the redundant workers lost their ability to repay their loans. Due to the growth of unemployment there was a drop of State's tax revenue, which in turn caused the decrease of GDP and economic crisis.

Iceland, whose population is only 320 thousand people, for many years was considered an oasis of prosperity, one of the richest countries in the world highly valued by foreign investors. Iceland's GDP was increasing by approx. $5-7 \%$ a year, and the base of the Icelandic economy was fishing, tourism and processing of aluminium. An important role was also played by the banks, which developed activities abroad and their foreign assets exceeded ten times the GDP, what became the key reason for the country's problems. At the end of 2008 - when the crisis was claiming the losses - it turned out that it plunged also Icelandic financial institutions, which were too large for such a small scale country. Icelandic banks were not able to continue its activities, which led to a strong weakening of the Icelandic krona, as well as has prompted the Icelandic government to nationalize those institutions (Sytuacja gospodarcza ..., p. 1 and next).

\section{Economic crisis in Poland}

The global economic crisis relatively quickly arrived to the countries of Central and Eastern Europe, causing a rapid suppression of growth of GDP and widespread recession. The return of economic growth was not possible without making a number of important reforms, which aim at raising the investment attractiveness and competitive strength of countries in the region. Prolonged recession or economic stagnation in Western Europe in a simple manner resulted in a period of economic troubles of Poland manifested by an increase in unemployment and a slowdown in wage and income dynam- 
ics, and the fall of imports by $28 \%$ and of exports by more than $26 \%$ in 2009 was not unique neither in the world nor in the region (Rocznik Statystyczny Handlu ..., p. 41-50).

Polish economy experienced during the crisis some of the best economic performance in the region. Despite the decline in exports, domestic demand grew, but at a much slower pace than before the crisis. The degree of dependence on exports of Polish economy was much smaller than the average level among Central European countries. This is because, inter alia, Poland is - next to Russia - the only country in the region with a large internal market.

In comparison to the majority of the countries of the region, Polish economy is characterized by relatively moderate degree of dependency from external financing. It is the result of relatively low investment rates, with moderate savings rates. These factors contribute to the fact that in spite of certain threats to the macroeconomic stability, which appeared in the first months of 2009, the situation of Polish economy looked rather preferably (Polska wobec ..., p. 18 and next).

In response to the progressive crisis, Polish state institutions carried out the intervention tasks according to the following division of roles (Polski rynek ..., p. 14 and next).

1) Office of the Financial Supervision Authority (FSA) led efforts to provide liquidity to Polish banks, in particular, to prevent the possible outflow of funds from the "subsidiaries” to „parent companies” in the framework of international capital groups, as well as to strengthen their capital base,

2) The National Bank of Poland (NBP), apart from standard instruments of implementing monetary policy, introduced mechanisms of temporary substitution of market, which could be critical if the action indicated above did not provide liquidity to banks,

3) The Ministry of Finance prepared instruments to support financial institutions which were at risk with the use of public funds, which could be used, if previously applied stabilizers turned out to be insufficient.

Relative financial stability and the high creditworthiness of Poland (rating A - with stable outlook according to the classification of Standard\&Poor's) allowed for relatively safe financing of the borrowing needs. This meant a moderate risk of external instability during the peak of the crisis, additionally reduced by the IMF flexible credit line (open credit line amounting to 20 billion USD, which Poland can use in case of problems with financial stability). 
Table 1. Actions important because of the crisis on the domestic market

\begin{tabular}{|c|c|c|}
\hline FSA and its Office & National Bank of Poland & Ministry of Finance \\
\hline $\begin{array}{l}\text { - limitation of the dynam- } \\
\text { ics of foreign-currency } \\
\text { indexed credit portfolio, } \\
\text { - passing the liquidity act, } \\
\text { - monitoring of intragroup } \\
\text { transactions, } \\
\text { - tightening concentration } \\
\text { limits for banks, } \\
\text { - limitation of the risks } \\
\text { of concentration of in- } \\
\text { vestments of insurance } \\
\text { companies, } \\
\text { - retention of profit in } \\
\text { banks (also selectively in } \\
\text { insurance), } \\
\text { - limiting the role of subor- } \\
\text { dinated loans in the capi- } \\
\text { tal of banks, } \\
\text { - introduction of a mecha- } \\
\text { nism of including bonds } \\
\text { to banks' capital, } \\
\text { - estimation of total posi- } \\
\text { tion and pricing of option, } \\
\text { - tightening of recommen- } \\
\text { dations for banks using } \\
\text { derivatives. }\end{array}$ & $\begin{array}{l}\text { - Implementation of the } \\
\text { "Confidence Package": } \\
\text { - repo transactions, } \\
\text { - currency swaps, } \\
\text { - easier access to the } \\
\text { Lombard loan, } \\
\text { - earlier redemption of } \\
\text { bonds, } \\
\text { - reduction of reserve } \\
\text { requirement rate, } \\
\text { - Implementation of the } \\
\text { "Pact for development of } \\
\text { lending": } \\
\text { - discount credit, } \\
\text { - preparation of reports } \\
\text { relating to the stability of } \\
\text { the banking system. }\end{array}$ & $\begin{array}{l}\text { - Announcement of "Sta- } \\
\text { bility and Development } \\
\text { Plan": } \\
\text { - increasing the level of } \\
\text { bank deposit guarantees, } \\
\text { - creation of a mecha- } \\
\text { nism to support financial } \\
\text { institutions, } \\
\text { - introduction of the mech- } \\
\text { anism of decapitalisation } \\
\text { of threatened financial } \\
\text { institutions, } \\
\text { - extension of the govern- } \\
\text { ment guarantees system. }\end{array}$ \\
\hline
\end{tabular}

Source: own analysis based on: Polski rynek finansowy w obliczu kryzysu finansowego w latach 2008-2009, UKNF, Warszawa May 2010, p. 15-16.

In 2009 recession appeared in Euroland. During this period Poland directed $70 \%$ of its exports there, so it had to affect the Polish trade deficit. In July 2008 it amounted to 2 billion EUR, and in 2009 - 20 billion EUR. Foreign investments in Poland decreased by $16 \%$, and domestic investments - by $15 \%$. Inflation in Poland at the end of 2008 was maintained at $5 \%$. While the public debt of the Treasury in August 2008 increased to 529 billion PLN and its service in 2009 alone cost 33 billion PLN.

Banks in Poland reached very high profits, as they applied strict lending standards in the lending business. Besides, they did not grant subprime 
Ioans. These factors contributed particularly strongly to the protection of Polish from the drastic effects of the crisis (Polski rynek ..., p. 14 and next).

In the period from August 2008 to March 2009, PLN's exchange rate fell by about $40 \%$. This had important consequences for the Polish slowing economy, including, inter alia: for the economic-financial condition of exporters and importers and the economic operators which were indebted in foreign currencies (Program konwergencji ..., p. 10).

In October 2008, the NBP launched a package of confidence, which aimed at, in particular, reduction of the liquidity risk of banks and their currency risk. Then, in order to stimulate economic activity, Monetary Policy Council eased significantly the monetary policy, lowering the basic interest rates of the NBP (Polska wobec ..., p. 38-45). In view of the deteriorating macroeconomic situation on April 27th 2009 the Conditions of the implementation of the next stages of the Roadmap for Euro Adoption in Poland. This document presents the conditions for safe participation in ERM II. First of all, the level of fixed parity should be consistent with macroeconomic situation of Poland (Uwarunkowania ...).

Secondly: the period of participation in ERM $I^{5}$ should be short, which would move towards the moment of adoption of the common currency and would increase the credibility of the current level of parity as a reference point for the final exchange rate of the PLN to the EUR.

Thirdly: when assessing readiness for euro adoption, Poland should meet all the formal conditions for membership in the euro area.

Lastly: it was necessary to reach a political agreement on the issue of conducting the necessary formal adjustments to adopt the euro.

The actions heading to restore the public finances were presented in January 2010; at that time, the Plan for Development and Consolidation of Finances 2010-2011 (Program konwergencji ..., p. 13-14).

As you can see, the room for manoeuvre of economic policy in Poland has been greatly reduced. It was the effect of cumulating the fiscal imbalance, which was not predicted in the previous years. That is why the package of

\footnotetext{
${ }^{5}$ Exchange Rate Mechanism, ERM - the mechanism for the mutual stabilization of the currencies of the Member States of the European Economic Community. ERM II is a system that combines the euro currency with the currencies of EU countries outside the euro area. The purpose of ERM II is to allow the smooth operation of the Internal Market by maintaining the stability of exchange rates of the Member States, since large fluctuations would lead to the fact that the products of one of the countries would become more competitive only because of the changes in exchange rate.
} 
anticrisis measures in Poland was much more economical in financial terms than in many other economies. However, there were also voices that the government, in which the neoliberals had a strong position, did not use all the existing possibilities, in order to stimulate the demand and as a result decrease the negative effects of the global financial and economic crisis.

The main element of anticrisis measures in Poland was the Plan of Stability and Development - strengthening the Polish economy against the global financial crisis, which was introduced by the government of November $30^{\text {th }}$ 2008. Its aim was to strengthen Polish economy against the global financial crisis and to stabilize the banking system. It must be stressed that in the second case, the actions taken were of clearly preventive nature.

As part of the above mentioned plan, inter alia, the following actions were taken (Program konwergencji ..., p. 12-13):

1 ) the guarantee of the solvency of bank deposits of Poles was increased to 50 thousand EUR;

2) there were savings made in the State budget;

3) the guarantee limit and Treasury guarantees were increased to 40 billion PLN, and then to 55 billion PLN;

4) subsidized housing loans were launched for people who due to job loss were not able to repay loans taken to buy their own homes;

5) The Bank Gospodarstwa Krajowego was recapitalized with the amount of 3.7 billion PLN, thus the system of guarantees for small and medium enterprises was strengthened;

6) a higher investment allowance (up to 100 thousand. EUR) for start-ups was introduced;

7) the restrictions on obtaining advances, inter alia, for companies applying for EU subsidies were abolished;

8) the rate of growth in energy prices was stopped;

9) including spending on research to the tax costs was allowed. The value of planned anti-crisis measures amounted to 91.3 billion PLN. The normative solution set out as a remedy for the crisis was the Act of 1 July 2009 on mitigating the effects of the economic crisis for employees and entrepreneurs (Journal of Laws of 2009, no. 125, item 1035 as amended). The anticrisis act introduced changes in:

1) the Act of $26^{\text {th }}$ of July 1991 on income tax from individuals (Journal of Laws of 2016, item 2032 as amended);

2 ) the Act of $15^{\text {th }}$ of February 1992 on corporation tax (Journal of Laws of 2016, item 1888 as amended); 
3 ) the Act of $20^{\text {th }}$ of April 2004 on employment promotion and labour market institutions (Journal of Laws of 2008, No 69, item 415 as amended);

4) the Act of $13^{\text {th }}$ of July 2006 on the protection of workers' claims in the event of insolvency of their employer (Journal of Laws No 158, item 1121 as amended).

The law - at the time of its application - introduces changes in existing principles of working time account, primarily by extending the settlement period, extending the applicability of individual working time schedule - also by reducing the basis of employment, it limits the possibility of employment under fixed-term contracts, not by their number and the interval between successive agreements, but for a limited in time combined period of their duration. Regulates the granting, payment and reimbursement of benefits from the Guaranteed Employee Benefits Fund and of means for subsidize training costs, payment of scholarships for workers from the Labor Fund.

As indicated in the explanatory memorandum to the act due to changes in the organization of working time by entrepreneurs in companies affected by the economic crisis and due to benefits granted to employees for subsidized employment:

- labour costs may be reduced, and thus the financial situation of businesses can be improved during the economic downturn,

- employment levels, and therefore readiness to take up the activities for the improvement of the economic situation, will be maintained and

- competitiveness of business will be maintained.

The idea was to allow the use of payment period for the adjustment of business to the changing market conditions.

Other actions that strengthen the Polish economy and improve the condition of public finances, included:

1) the implementation of bridging pension reform,

2) privatization,

3) The amendment to the Public Finance Act, ordering its structure.

Apart from that, in May 2009 Poland signed the agreement with IMF on the availability of flexible credit line. Based on the agreement with the IMF for one year Poland gained access to approx. 20.5 billion USD, supplying foreign exchange reserves of the central bank. These measures could be used in case of changes threatening the stability of the banking system.

The cost of giving Poland the access to flexible credit line by the IMF burdened the result of central bank. Although Poland did not use the granted funds, the government repeatedly declared, that the extension of the agreement with the IMF would be advisable due to the continuing uncertainty in 
the markets. For its part, National Bank of Poland, which had to accept a request to update the agreement with the IMF, said that reapplying by Poland for access to the flexible credit line would not be justified.

NBP then pointed out that the current state of foreign exchange reserves is sufficient security buffer for the banking system in Poland. He noted, however, that if the Minister of Finance found it reasonable to obtain Poland's access to the credit line in connection with the occurrence of fiscal factors, which may affect the balance of payments, the National Bank of Poland would be prepared to support the government's efforts in this respect (Brzeziński, 2010).

\section{References}

Adamczyk M. (2012). Współczesny kryzys finansowy - przyczyny i konsekwencje dla gospodarki światowej. Wyzwania gospodarki globalnej. Prace i Materiały Instytutu Handlu Zagranicznego Uniwersytetu Gdańskiego, 31.

Adamiec J., Russel, P. (2009). Światowy kryzys gospodarczy a sektor przedsiębiorstw i gospodarstw domowych w Polsce. In J. Adamiec (Ed.), Kryzys finansowy wybrane zagadnienia. Wydawnictwo Sejmowe. Warszawa.

Brzeziński T. (2010). Rząd chce wciąż mieć dostęp do pieniędzy MFW. In Rzeczpospolita of $4^{\text {th }}$ May 2010 and Kiedy wniosek rządu trafi do funduszu. Parkiet Gazeta Giełdy, of $5^{\text {th }}$ May.

Emergency Economic Stabilization Act of 2008 (EESA).

Firlej K. A., (2011). Źródła i przebieg kryzysu finansowego w Stanach Zjednoczonych i Europie Zachodniej. Roczniki Ekonomiczne Kujawsko-Pomorskiej Szkoły Wyższej w Bydgoszczy, 4.

Journal of Laws (2009), 125, item 1035 as amended.

Kołodko G., (2010). Świat na wyciągnięcie myśli. Prószyński i S-ka. Warszawa 2010. Krawczyk-Sawicka A., (2016), Problems with fulfilment of stabilization pact in the face of the financial crisis of the Eurozone, Central European Review of Economics \& Finance Vol. 13, No. 3.

Małkiewicz A., Kryzys. Polityczne, ekologiczne i ekonomiczne uwarunkowania. Wydawnictwo Naukowe Scholar. Warszawa.

Polska wobec światowego kryzysu gospodarczego (2009). NBP. Warszawa, September.

Polski rynek finansowy w obliczu kryzysu finansowego w latach 2008-2009. (2010) UKNF. Warszawa, May. 
Program konwergencji. Aktualizacja 2009 (2010). Warszawa, February.

Prosser B., (2008). Globalny kryzys finansowy. "FIN-FOCUS", 5.

Rocznik Statystyczny Handlu Zagranicznego 2010. (2010) GUS. Warszawa.

Rymarczyk J. (2010). Globalny kryzys finansowy. In M. Lasoń (Ed.). Między kryzysem a współpracą gospodarczą. Oficyna Wydawnicza AFM. Kraków.

Sytuacja gospodarcza w Grecji, Hiszpanii, Irlandii, Islandii, Estonii, na Litwie i Łotwie oraz w Polsce - skutki kryzysu (2010). Kancelaria Senatu Biuro Analiz i Dokumentacji. Warszawa.

Uwarunkowania realizacji kolejnych etapów Mapy Drogowej Przyjęcia Euro przez Polskę (2009). Ministerstwo Finansów. Warszawa, April.

Uzasadnienie do projektu ustawy 13 lipca 2006 r. o ochronie roszczeń pracowniczych w razie niewypłacalności pracodawcy (Dz. U. nr 158, poz. 1121 z późn. zm.). 